57. Pettinger A, Nettleman MD. Epidemiology of isolation precautions. Infect Control Hosp Epidemiol 1991;12:303-307.

58. Pittet D, Mourouga P, Perneger TV. Compliance with handwashing in a teaching hospital. Ann Intern Med 1999;130:126-130.

59. Fridkin SA, Pear SM, Williamson TH, Galgiani JN, Jarvis WR. The role of understaffing in central venous catheter-associated bloodstream infections. Infect Control Hosp Epidemiol 1996;17:150-158.

60. Farr BM. Understaffing: a risk factor for infection in the era of downsizing? Infect Control Hosp Epidemiol 1996;17:150-158.

61. Newman JL, Seitz JC. Intermittent use of an antimicrobial hand gel for reducing soap-induced irritation of health care personnel. Am J Infect Control 1990;18:194-200.

62. Ojajarvi J. Handwashing in Finland. J Hosp Infect 1991;18:35-40.

63. Boyce JM. Kelliher S, Vallande N. Skin irritation and dryness associated with two hand-hygiene regimens: soap and water hand washing versus hand antisepsis with an alcoholic hand gel. Infect Control Hosp Epidemiol. In press.

64. Pittet $\mathrm{D}$. Improving hand-hygiene adherence using a multidisciplinary approach. Presented at the 4th Decennial International Conference on Nosocomial and Healthcare Associated Infections in conjunction with the 10th Annual Meeting of the Society for Healthcare Epidemiology of
America; March 4-9, 2000; Atlanta, GA.

65. Larson, EL. Compliance obstacles and measures to increase compliance in traditional non-traditional areas. Presented at the Ninth Annual Meeting of the Society for Healthcare Epidemiology of America; April 18-20, 1999; San Francisco, CA. Symposium IV.

66. Hayden F. Preventing influenza in acute care settings. Presented at the CDC 4th Decennial International Conference on Nosocomial and Healthcare-Associated Infections in conjunction with the 10th Annual Meeting of the Society for Healthcare Epidemiology of America; March 4-9, 2000; Atlanta, GA.

67. Thompson RL, Cabezudo I, Wenzel RP. Epidemiology of nonsocial infections caused by methicillin-resistant Staphylococcus aureus. Ann Intern Med 1982;97:309-317.

68. Monnet D. Plenary Session. Global Conference on Antibiotic Resistance; March 1999; Toronto, Ontario, Canada.

69. Bager F, ed. DANMAP 98-Consumption of Antimicrobial Agents and Occurrence of Antimicrobial Resistance in Bacteria From Food Animals, Food and Humans in Denmark. Copenhagen, Denmark: Danish Zoonosis Centre; 1999. Available from http://www.svs.dk/dk/z/Danmap\%201998.pd (Note: to view, rename suffix “.pdf".)

\title{
New APIC Guideline for Infection Prevention and Control in Flexible Endoscopy
}

\section{Gina Pugliese, RN, MS \\ Martin S. Favero, PhD}

The first Association of Practitioners in Infection Control (APIC) guideline for infection prevention and control in flexible endoscopy was published in $1994(\mathrm{Am} J$ Infect Control 1994;2:19-38). This guideline was followed by a multisociety position statement endorsed by the American Society for Gastrointestinal Endoscopy, the Society of Gastroenterology Nurses and Associates, the American Gastroenterological Association, the
American College of Gastroenterology, and APIC (Gastrointest Endosc 1996;43:540546). In 1997, a monograph on standards for infection control and reprocessing of flexible gastrointestinal endoscopes developed by the Society for Gastroenterology Nurses and Associates offered specific recommendations in a highly detailed, step-bystep fashion (Gastroenterol Nurs 1997;20 [suppl]:1-13).

This new APIC guideline reflects all these efforts and provides an update in this important area. The guideline is divided into the following sections: Infectious Complications of Flexible Endoscopy;
Flexible Endoscopes Structure and Design; Processing of Endoscopes and Accessories; Reuse of Single-Use Endoscopy Devices/ Accessories; Quality Control-Assessment of the Adequacy of Disinfection/Sterilization; Outbreak Management; Design of Facilities for Performing Endoscopic Procedures, Including Support; Space; Endoscopy Personnel; Product Development and Areas for Future Investigation; and Recommendations.

FROM: Alvarado CJ, Reichelderfer M. APIC guideline for infection prevention and control in flexible endoscopy. $A m I$ Infect Control 2000;28:138-155. 